Provided for non-commercial research and education use. Not for reproduction, distribution or commercial use.

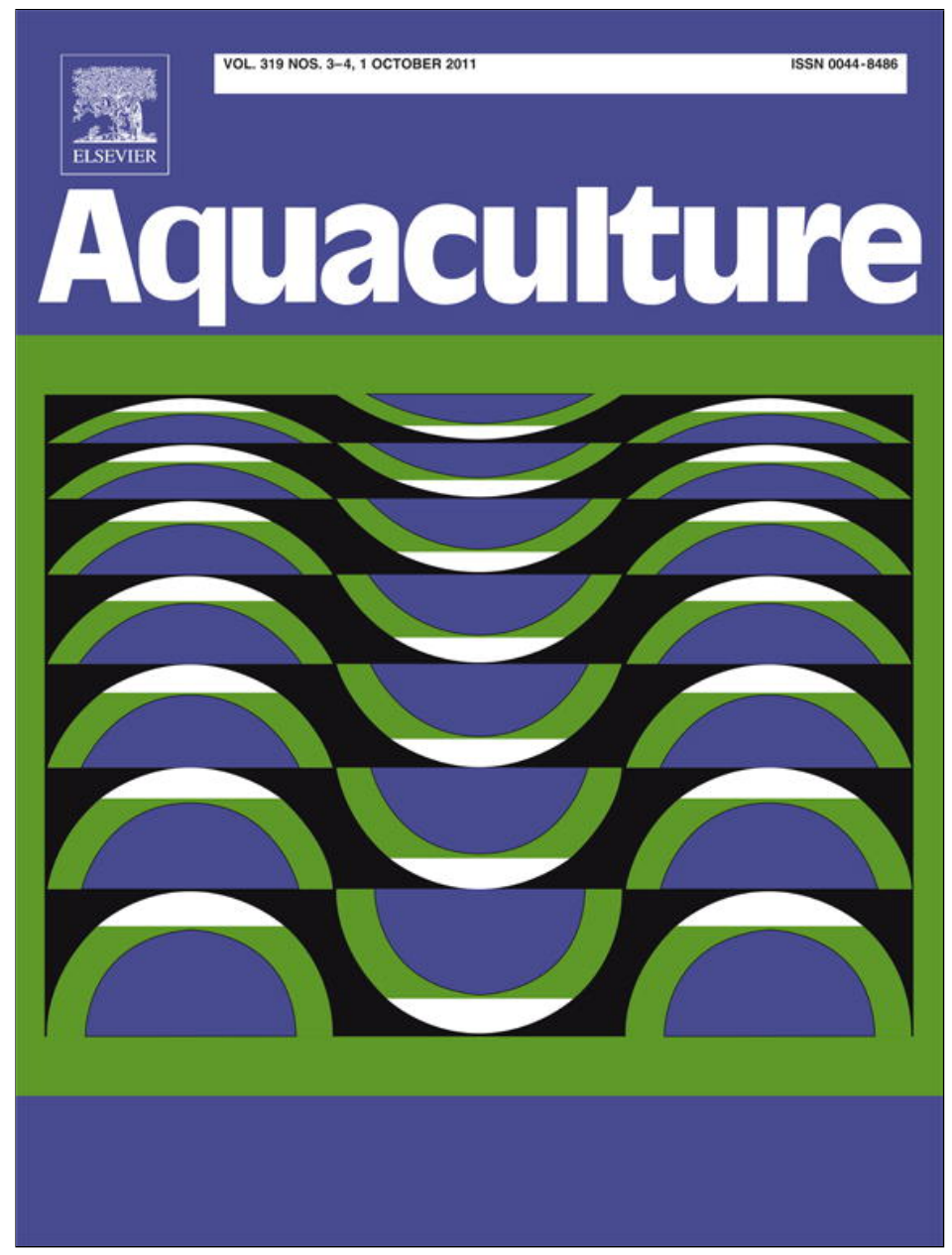

This article appeared in a journal published by Elsevier. The attached copy is furnished to the author for internal non-commercial research and education use, including for instruction at the authors institution and sharing with colleagues.

Other uses, including reproduction and distribution, or selling or licensing copies, or posting to personal, institutional or third party websites are prohibited.

In most cases authors are permitted to post their version of the article (e.g. in Word or Tex form) to their personal website or institutional repository. Authors requiring further information regarding Elsevier's archiving and manuscript policies are encouraged to visit:

http://www.elsevier.com/copyright 


\title{
Growth performance and condition of oysters (Crassostrea gigas and Ostrea edulis) farmed in an offshore environment (North Sea, Germany)
}

\author{
B. Pogoda ${ }^{\text {a,b,* }}$, B.H. Buck ${ }^{\text {b,c,d }}$, W. Hagen ${ }^{\text {a }}$ \\ a University of Bremen, Marine Zoology, p.o. Box 330440, 28334 Bremen, Germany \\ ${ }^{\mathrm{b}}$ Alfred Wegener Institute for Polar and Marine Research (AWI), Am Handelshafen 12, 27550 Bremerhaven, Germany \\ ${ }^{\mathrm{c}}$ Institute for Marine Resources (IMARE), Bussestrasse 27, 27570 Bremerhaven, Germany \\ d Bremerhaven University of Applied Sciences, Applied Marine Biology, An der Karlstadt 8, 27568 Bremerhaven, Germany
}

\section{A R T I C L E I N F O}

\section{Article history:}

Received 4 March 2011

Received in revised form 12 July 2011

Accepted 14 July 2011

Available online 23 July 2011

\section{Keywords:}

Offshore aquaculture

Crassostrea gigas

Ostrea edulis

Multi-use

Site selection

\begin{abstract}
A B S T R A C T
Aquaculture production plays an increasingly important role to meet the global demand for aquatic products and expands continuously. Most mariculture organisms are produced in coastal areas, where space is scarce and user conflicts exist. For extensive cultures farming off the coast at offshore sites could be a solution to eliminate these problems and facilitate further expansion of environmentally sustainable aquaculture. The aim of this study was to examine the biological adequacy of two candidate species for ostreiculture, the Pacific oyster Crassostrea gigas and the European flat oyster Ostrea edulis. Growth rates, condition and mortality in offshore environments were investigated by transferring oyster spat of both species to 4 different sites in 2004 and 2007. Samples were taken every six to eight weeks from April to October and length, width, height and dry mass were measured as well as the Condition Index $(\mathrm{CI}=$ dry mass meat $\cdot 100 /$ dry mass shell $)$ was calculated. Results show that both oyster species grow successfully in a high-energy environment. Mean growth rates are similar to those measured in individuals from coastal habitats (wild banks and cultures) and the CI shows seasonal variation in both species. The survival rate for both species was $>99 \%$ in 2007. However, in the previous trial in 2004 a high mortality rate was observed for 0. edulis at one single site at the end of the experiment. Differences were observed in the increase of shell length and dry mass between sites and size classes. Taking these results into account site-selection criteria for different offshore locations are presented. We conclude that offshore cultivation of oysters will be successful if site-selection criteria are examined carefully when choosing a location for offshore aquaculture.
\end{abstract}

(c) 2011 Elsevier B.V. All rights reserved.

\section{Introduction}

Aquaculture is the fastest-growing sector of food production worldwide (FAO, 2009). The production of marine organisms mainly takes place in sheltered areas or embayment of the coastal sea (Buck et al., 2003; Firestone et al., 2004). However, in coastal areas space for all kinds of utilization is scarce, thus user conflicts exist and permanently increase (Buck et al., 2004; Wirtz et al., 2002). Intensive seafood production (e.g. fish or shrimp) often generates environmental stress caused by chemicals, eutrophication and impacts on benthic communities (McElwee, 1998). Therefore, in most nearshore areas the ecological carrying capacity sets limitations to massive expansions of intensive aquaculture activities (Troell et al., 2009). Extensive cultivation methods and extractive culture species with modest service needs offer the chance to move to offshore areas, away from socio-economic conflicts and coastal pollution (Krause et al., 2003) and still have an economic potential (Buck et al., 2010). Offshore or

* Corresponding author at: University of Bremen, Marine Zoology, p.o. Box 330440, 28334 Bremen, Germany. Tel.: + 4942121863037 ; fax: + 4942121863055.

E-mail address: bernadette.pogoda@uni-bremen.de (B. Pogoda). open-ocean aquaculture stands for the move of aquaculture operations from sheltered nearshore areas to more exposed environments where high wave action and strong currents exist (Ryan, 2005). However, due to the strong exchange and dilution effects of the water column in these high-energy environments, the water quality, the major element in aquaculture operations, is regarded to be very good (BSH 2006; Takayanagi, 1998).

Less user conflicts and higher wind speeds in offshore regions also enhance growing interests in offshore wind farming. Worldwide wind farms in offshore areas are being planned or already under construction (Gierloff-Emden, 2002). Following the multi-use concept of the Alfred Wegener Institute for Polar and Marine Research (AWI) and the Institute for Marine Resources (IMARE) foundations of offshore wind turbines can be used for additional purposes. Therefore, aquaculture installations can be attached to or installed between turbines within a wind farm (e.g. Buck \& Krause 2011; Buck et al., 2008). Following these concepts of multifunctional use, sustainable seafood production shows an enormous economic potential in offshore areas (Buck et al., 2008).

Shellfish aquaculture, particularly oyster and mussel cultivation, is a good example for extensive production and has become very attractive (Gibbs, 2004). These candidates do not require artificial feeding 


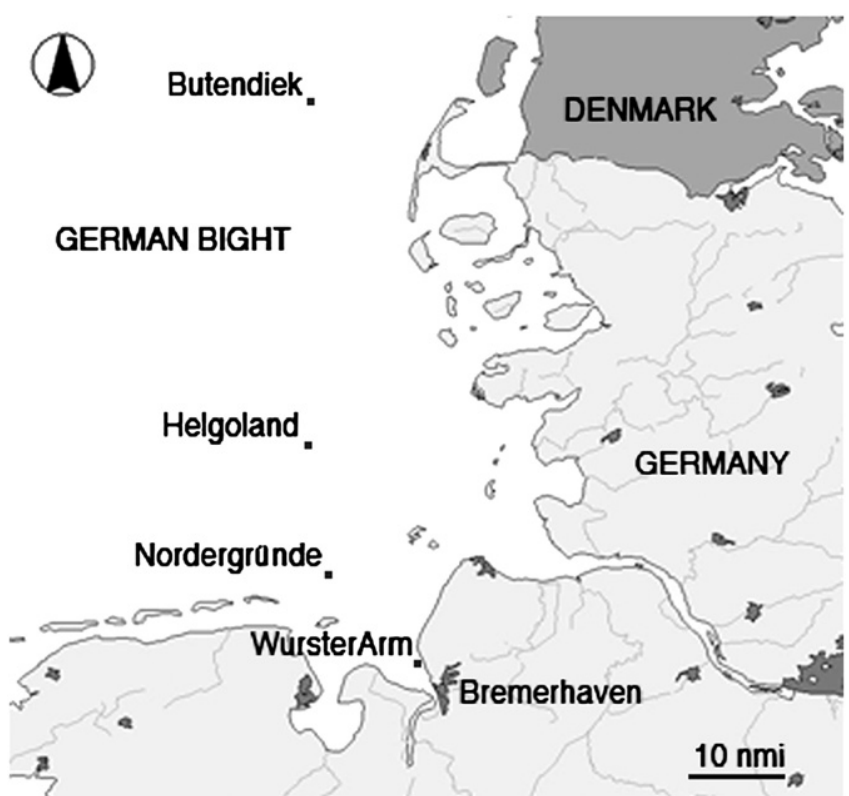

Fig. 1. Map of the German Bight showing all test sites: Butendiek (BD), Helgoland (HE), Wurster Arm (WA), and Nordergründe (NG).

(Ferreira et al. 2009; Garen et al., 2004) and as essential bio-extractive organisms can even improve water quality in marine systems (Ferreira et al., 2009; Rose et al., 2010). A feasibility study on open-ocean aquaculture by Buck (2002) identified the following extractive candidates as most suitable for the North Sea: sugar kelp (Laminaria saccharina/Saccharina latissima), dulse (Palmaria palmata), blue mussel (Mytilus edulis) and two oyster species, the Pacific oyster (Crassostrea gigas) and the European flat oyster (Ostrea edulis). As oysters represent high-value products and realize high prices on the market, compared to other shellfish (FAO 2011; Troell et al., 2009), these organisms seem to be ideal candidates for offshore aquaculture. However, techniques for offshore cultivation of oysters have not been developed yet, as over centuries, different forms of oyster cultures were only developed in coastal areas (Burbridge et al., 2001).

Consequently, no information is available on growth performance and fitness of oysters farmed in offshore areas, which experience high-energy environments. From the biological perspective the present study aims to assess whether offshore oyster cultivation offers a promising potential regarding growth performance in rough conditions.

This is the first study focusing on cultivation and subsequent performance characteristics of the Pacific oyster ( $C$. gigas) and the European flat oyster (O. edulis), exposed to offshore farming conditions. In two experiments (2004 and 2007) we examined growth performance, condition and survival of oysters and analyzed site-specific criteria for the cultivation at offshore sites in the North Sea (Germany).

\section{Materials and methods}

\subsection{Origin of test animals and description of study sites}

Juvenile oysters were obtained from commercial hatcheries. For the sampling season 2004 O. edulis was produced at the Danish Shellfish Centre (Denmark) in September 2003 (observed as veliger) and C. gigas at Guernsey Seafarms (UK) in July 2003. For the sampling season 2007 oysters of 0 . edulis were produced in April 2006 (observed as veliger) at Bømlo Skjell A. Musling (Norway). C. gigas spat (produced in July 2006) was obtained from Guernsey Seafarms as well. Initial size classes (shell length) of juvenile oysters were 10$20 \mathrm{~mm}$ in 2004 and $20-30 \mathrm{~mm}$ in 2007. For the cultivation under offshore conditions juveniles of both species were transferred to the test sites in April 2004 (preliminary experiment for site selection) as well as in April 2007 (main experiment).

In the preliminary experiment oysters were cultivated in three different areas of the German Bight (Fig. 1). These study sites are characterized by various hydrographic features, such as depth, condition of the sea bottom, wave exposure, current velocity and significant wave heights (BSH 2011; Mittelstaedt et al., 1983), which are shown in Table 1. The site-specific conditions of these areas were chosen to fulfill the offshore-criteria in terms of a high-energy environment following the definition of Ryan (2005). Two test sites were set up within the areas of projected wind farms to underline the idea of the multiple-use concept. Furthermore, accessibility to sample and service the sites was also taken into account but of secondary relevance.

The test site Butendiek (BD) was located 15 nautical miles (nmi) west of the northern tip of the North Frisian island of Sylt ( $54^{\circ} 59,1^{\prime} \mathrm{N}$; $\left.007^{\circ} 54,4^{\prime} \mathrm{E}\right)$. Water depth was approximately $16 \mathrm{~m}$ at mean high water (MHW). This site was chosen because it is located within the area of the planned wind farm "Butendiek". The rounded metal piles of a former research platform of the Federal Maritime and Hydrographic Agency (Buck et al. 2008) provided an adequate fixed position within an offshore (high-energy) environment, and were used as a holding device for the oysters. A permit for the utilization of the study site was obtained in March 2004. Cultures were mounted at $4 \mathrm{~m}$ depth (high tide). The test site Helgoland (HE) was set up northeast of the island of Helgoland ( $\left.54^{\circ} 11,4^{\prime} \mathrm{N} ; 007^{\circ} 53,0^{\prime} \mathrm{E}\right)$. Water depth at site was approximately $6 \mathrm{~m}$ at MHW. Cultures were mounted to a metal frame at $4 \mathrm{~m}$ depth of water (high tide). The metal frame was moored on the seabed and co-used as a test site for the settlement of Mytilus edulis post-larvae. Despite the fact that this test site was about $150 \mathrm{~m}$ off the island of Helgoland, it can be considered as an offshore site due to the typical conditions that characterize this location (strong currents, high waves, good water quality, deep enough for submerged cultures (Barnaby, 2006)) and the fact that Helgoland is defined as an offshore island at all. The test site Wurster Arm (WA) was located in the outer Weser estuary $\left(53^{\circ} 40,7^{\prime} \mathrm{N} ; 008^{\circ} 24,5^{\prime} \mathrm{E}\right)$. Water depth at the site was approximately $8.5 \mathrm{~m}$ at MHW. Cultures were mounted at $1.5 \mathrm{~m}$ depth below a navigation buoy of the Water and Shipping Agency (WSA) Bremerhaven and were therefore independent of tidal influence. The main experiment started in 2007 and cultivation was carried out at a

Table 1

Site-specific conditions and classification of the four test sites.

\begin{tabular}{|c|c|c|c|c|c|c|c|c|c|c|c|}
\hline Test site & Code & Year & $\begin{array}{l}\text { Distance to } \\
\text { coast [nmi] }\end{array}$ & Classification & $\begin{array}{l}\text { Depth at } \\
\text { MHW } \\
{[\mathrm{m}]}\end{array}$ & $\begin{array}{l}\text { Sediment type } \\
\text { at sea bottom }\end{array}$ & $\begin{array}{l}\text { Sediment load } \\
\text { of water column }\end{array}$ & $\begin{array}{l}\text { Significant } \\
\text { wave height } \\
{[\mathrm{m}]^{\mathrm{a}}}\end{array}$ & $\begin{array}{l}\text { Wave } \\
\text { exposure }\end{array}$ & $\begin{array}{l}\text { Current } \\
\text { velocity } \\
{[\mathrm{m} / \mathrm{s}]^{\mathrm{a}, \mathrm{b}}}\end{array}$ & $\begin{array}{l}\text { Max. daily tidal } \\
\text { current velocity } \\
{[\mathrm{m} / \mathrm{s}]^{\text {a }}}\end{array}$ \\
\hline Butendiek & $\mathrm{BD}$ & 2004 & 17 & Offshore & 14,8 & Sand & Low & $0.4-5.1$ & Exposed & $0.2-0.6$ & 0.32 \\
\hline Helgoland & $\mathrm{HE}$ & 2004 & 25 & Semi-offshore & 6,0 & Sand & Low & $0.5-4.0$ & Exposed & $0.1-0.7$ & 0.30 \\
\hline Wurster Arm & WA & 2004 & 3 & Nearshore & 8,5 & Mud (clay) & High & $0.2-1.8$ & Moderate & $0.3-0.7$ & 0.45 \\
\hline Nordergründe & NG & 2007 & 9 & Offshore & 11,5 & Sand & Moderate & $0.5-5.0$ & Exposed & $0.2-0.8$ & 0.34 \\
\hline
\end{tabular}

nmi: nautical mile, MHW: mean high water.

a BSH 2011.

b Mittelstaedt et al. 1983. 
forth test site called Nordergründe (NG), which was located in the outer Weser estuary $\left(53^{\circ} 51,0^{\prime} \mathrm{N} ; 008^{\circ} 04,0^{\prime} \mathrm{E}\right)$, approximately $17 \mathrm{nmi}$ northwest of Bremerhaven. It was situated in an official research testing area (Buck, 2007), which was established for offshore aquaculture as a multi-use in offshore wind farms. The planned offshore wind farm "Nordergründe" (Energiekontor, 2011) is located about one nmi off the test site. Experimental oysters were permanently submerged at all four testing sites.

\subsection{Experimental design and sampling}

In temperate regions both oyster species show an inactive period during winter and start feeding in spring (Løfstedt, 2010; Matthiessen, 2001). Therefore, our experiments were conducted over one complete growing season (first cultivation year) from April to October (Matthiessen, 2001; Robert et al., 1991; Walne \& Mann, 1975). Due to the sensitivity of oysters in their early juvenile stage, the first year of cultivation can be considered as the most critical period (Newkirk et al., 1995). Therefore, the present study focused on this period to elucidate survival and robustness of the two species.

The oysters were reared in small oyster lanterns $(60 \mathrm{~cm}$ length, $16 \mathrm{~cm}$ diameter, 4 compartments arranged in vertical levels, mesh size $10 \times 10 \mathrm{~mm}$ ), which were specifically produced for offshore aquaculture experiments (Fig. 2A). In both experiments 600 individuals were reared in each lantern (150 per compartment, two compartments with $O$. edulis and two with $C$. gigas), respectively. In the preliminary experiment (2004) two lanterns were installed at each site, attached to a metal frame, which acted as a rigid holding device. In the main experiment (2007) two lanterns were fixed to rigid steel rings, which were welded to large offshore marker buoys (Fig. 2B). These test buoys were constructed specifically for offshore aquaculture research on shellfish candidates (e.g. C. gigas, O. edulis, Mytilus edulis) (Brenner et al., 2007). Samples (80 individuals of each species) were taken by SCUBA-divers in June, August and October in 2004 and 2007. To ease sampling and maintenance and to avoid the loss of test animals the complete lantern was detached from the holding device and transferred to a zodiac nearby. Each lantern was then opened and oysters collected. In contrast to usual procedures in aquaculture the animals were not sorted into different size classes. Maintenance was performed by cleaning the lantern nets from biofouling and by removing empty shells. Oyster lanterns were returned to the holding device right after sampling to avoid stress for the animals. Sampled oysters were carefully stored in containers and transferred to the research vessel.

\subsection{Analysis of growth, condition index and mortality}

On board the research vessel length, width and height were measured to the closest $0.1 \mathrm{~mm}$, before animals were stored deepfrozen $\left(-80^{\circ} \mathrm{C}\right)$ and transferred to the lab facilities at the AWI in Bremerhaven as well as to the University in Bremen. Empty shells were counted to estimate mortality rates. To determine dry mass (DM) and condition index (CI) soft tissue and shell of the test animals were freeze-dried (48 h, LYOVAC GT2, Leybold-Heraeus) and weighed (R200D, Sartorius). CI was then calculated by using Eq. (1), as suggested by Davenport \& Chen (1987) and Walne \& Mann (1975):

$\mathrm{CI}=\mathrm{DM}$ meat $(\mathrm{g}) \cdot 100 / \mathrm{DM}$ shell $(\mathrm{g})$

Selecting a condition index that is based on dry mass is expected to be quite accurate as it is independent of the high variability of intervalval fluid in oysters (Beninger \& Lucas, 1984).

\subsection{Environmental parameters}

Oceanographic parameters (current velocities, wave heights) were extracted from the Operational Circulation Model BSHcmod (BSH, 2011; Dick, 2001). Data describing temperature, salinity, chlorophyll $a$, phaeophytin $a$, nitrate and nitrite $\left(\mathrm{NO}_{\mathrm{X}}\right)$, particulate organic carbon (POC), and particulate organic nitrogen (PON) were obtained from the Marine Environmental Data Base (MUDAB, BSH, 2009) and Brenner (2009).

\subsection{Statistical analysis}

Means, standard deviations, standard errors of the mean (mean \pm $\mathrm{SE}$ ) and confidence intervals of growth rates and condition indices were calculated using MS-Excel software. Differences in growth and condition index between sites and species were tested by $t$-test (MS-Excel software) and considered to be significant when $p<0.05$.
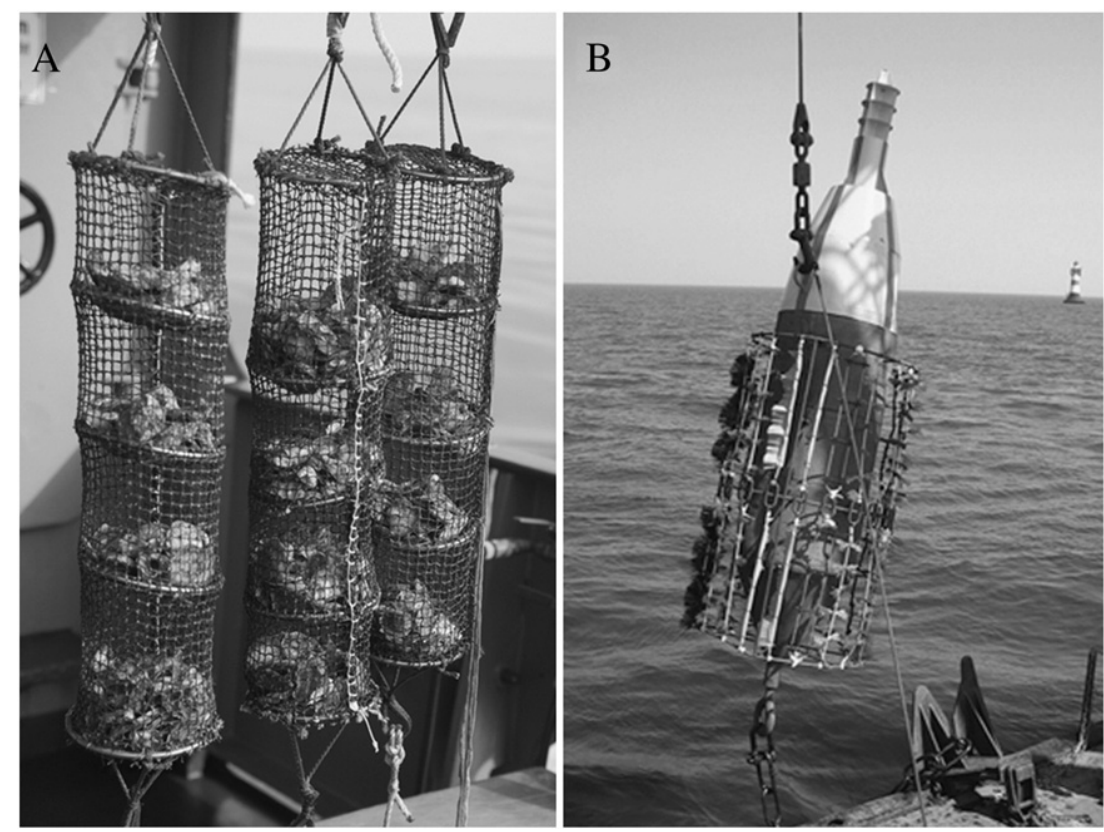

Fig. 2. (A) Oyster lanterns containing juveniles of Ostrea edulis and Crassostrea gigas. (B) Marker buoy, modified for offshore aquaculture research. Steel rings were used as rigid attachment device for the fixation of oyster lanterns. 


\section{Results}

The results of the preliminary experiment acted as the basis to determine the site for the main experiment: The site Nordergründe (NG) was chosen as it represents an offshore aquaculture location class 4 (Ryan, 2005) plus a similar situation as the site Butendiek (BD) but was easier to access due to its shorter distance from the city of Bremerhaven. Additionally, NG is situated within the official testing area mentioned above.

\subsection{Environmental conditions}

Environmental conditions at the test sites are displayed in Table 2. Temperature measurements showed comparable conditions at all three test sites in 2004. In spring and autumn 2007 temperature was slightly lower than in spring and autumn 2004. Salinity ranged between 29.4 and 33.6 at the offshore sites and was lower at the nearshore site (WA): Depending on the direction of the tidal current it ranged between 11.8 and 22.1. Chlorophyll and nutrient concentrations characterizing the suitability for shellfish cultivation at the sites were extracted from the Marine Environmental Data Base (BSH, 2009) and Brenner (2009) and are also shown in Table 2.

\subsection{Growth}

The average length of 0 . edulis was $11.2 \pm 0.2 \mathrm{~mm}$ at the beginning of the preliminary experiment (2004). At the end of the experiment it reached $27.9 \pm 0.4 \mathrm{~mm}$ at $\mathrm{WA}, 38.6 \pm 0.5 \mathrm{~mm}$ at $\mathrm{HE}$, and $42.0 \pm$ $0.9 \mathrm{~mm}$ at BD. The average length of $C$. gigas at the beginning of the experiment was $22.9 \pm 0.2 \mathrm{~mm}$. At the end of the experiment it reached an average length of $29.0 \pm 0.6 \mathrm{~mm}$ at WA, $47.1 \pm 0.9 \mathrm{~mm}$ near HE, and $50.5 \pm 1.1 \mathrm{~mm}$ at BD. C. gigas and O. edulis showed similar growth patterns in terms of shell length. Growth of young oysters was moderate during spring 2004 and increased in summer and autumn. Compared to the sites Butendiek (BD) and Helgoland (HE) a significantly slower growth $(p<0.01)$ was observed for both species at the site Wurster Arm (WA) (Fig. 3A-B).

At the beginning of the main experiment (2007) the average length of $O$. edulis was $38.5 \pm 0.5 \mathrm{~mm}$ and $24.7 \pm 0.5 \mathrm{~mm}$ of $C$. gigas. At the end of the experiment the average length of 0 . edulis was $58.9 \pm$ $0.8 \mathrm{~mm}$ and $55.3 \pm 1.1 \mathrm{~mm}$ of $C$. gigas, respectively. Both species showed rapid growth in spring, which slowed down in summer and increased again during autumn. Seasonal differences of growth rates were more pronounced in $C$. gigas than in 0 . edulis, which showed a

Table 2

Environmental parameters at the four test sites.

\begin{tabular}{|c|c|c|c|c|c|c|c|c|}
\hline \multicolumn{2}{|c|}{ Test site } & \multirow{2}{*}{$\begin{array}{l}\text { Temperature } \\
{\left[{ }^{\circ} \mathrm{C}\right]} \\
7.2\end{array}$} & \multirow{2}{*}{$\begin{array}{l}\text { Salinity } \\
32.9\end{array}$} & \multirow{2}{*}{$\begin{array}{l}\text { Chl } a \\
{[\mu \mathrm{g} / \mathrm{l}]}\end{array}$} & \multirow{2}{*}{$\begin{array}{l}\text { Pheo } a \\
{[\mu \mathrm{g} / \mathrm{l}]}\end{array}$} & \multirow{2}{*}{$\begin{array}{l}\begin{array}{l}\mathrm{POC} \\
{[\mu \mathrm{g} / \mathrm{l}]}\end{array} \\
512.2\end{array}$} & \multirow{2}{*}{$\begin{array}{l}\mathrm{PON} \\
{[\mu \mathrm{g} / \mathrm{l}]}\end{array}$} & \multirow{2}{*}{$\begin{array}{l}\mathrm{NO}_{\mathrm{X}} \\
{[\mu \mathrm{mol} / \mathrm{l}]}\end{array}$} \\
\hline BD & April & & & & & & & \\
\hline & June & 14.3 & 33.1 & 21.2 & 15.6 & 155.7 & 923.4 & 4.8 \\
\hline & August & 17.9 & 31.6 & 5.3 & 8.2 & 76.8 & 504.2 & 2.3 \\
\hline & October & 13.7 & 31.9 & 9.4 & 3.0 & 22.3 & 134.2 & 26.5 \\
\hline \multirow[t]{4}{*}{ HE } & April & 8.1 & 33.6 & 10.8 & n. d. & 486.3 & 67.8 & 30.5 \\
\hline & June & 14.1 & 33.5 & 21.2 & n. d. & n. d. & n. d. & 4.5 \\
\hline & August & 18.3 & 31.5 & 6.3 & n. d. & n. d. & n. d. & 0.7 \\
\hline & October & 14.0 & 32.9 & 3.7 & n. d. & 20.1 & 112.9 & 6.3 \\
\hline \multirow[t]{4}{*}{ WA } & April & 10.5 & 18.4 & 9.7 & 6.3 & 801.5 & 92.3 & 30.2 \\
\hline & June & 16.6 & 11.8 & 28.2 & 10.3 & 226.1 & 1015.8 & n. d. \\
\hline & August & 21.1 & 22.1 & 10.1 & 2.5 & 100.8 & 368.6 & n. d. \\
\hline & October & 12.9 & 19.7 & 7.2 & 5.7 & 24.2 & 78.2 & 11.6 \\
\hline \multirow[t]{4}{*}{ NG } & April & 6.0 & 31.8 & 6.0 & 0.9 & 1045.8 & 118.5 & 38.2 \\
\hline & June & 18.9 & 29.9 & 13.7 & 22.8 & 176.3 & 1518.6 & 7.7 \\
\hline & August & 18.0 & 32.1 & 8.8 & 14.2 & 87.0 & 456.6 & 7.9 \\
\hline & October & 11.1 & 29.4 & 6.3 & 3.2 & 18.5 & 130.0 & 7.1 \\
\hline
\end{tabular}

BD: Butendiek, HE: Helgoland, WA: Wurster Arm, NG: Nordergründe, Chl a: Chlorophyll $a$, Pheo a: Phaeophytin $a$, POC: particulate organic carbon, PON: particulate organic nitrogen, $\mathrm{NO}_{\mathrm{x}}$ : nitrate + nitrite, n.d.: no data available.
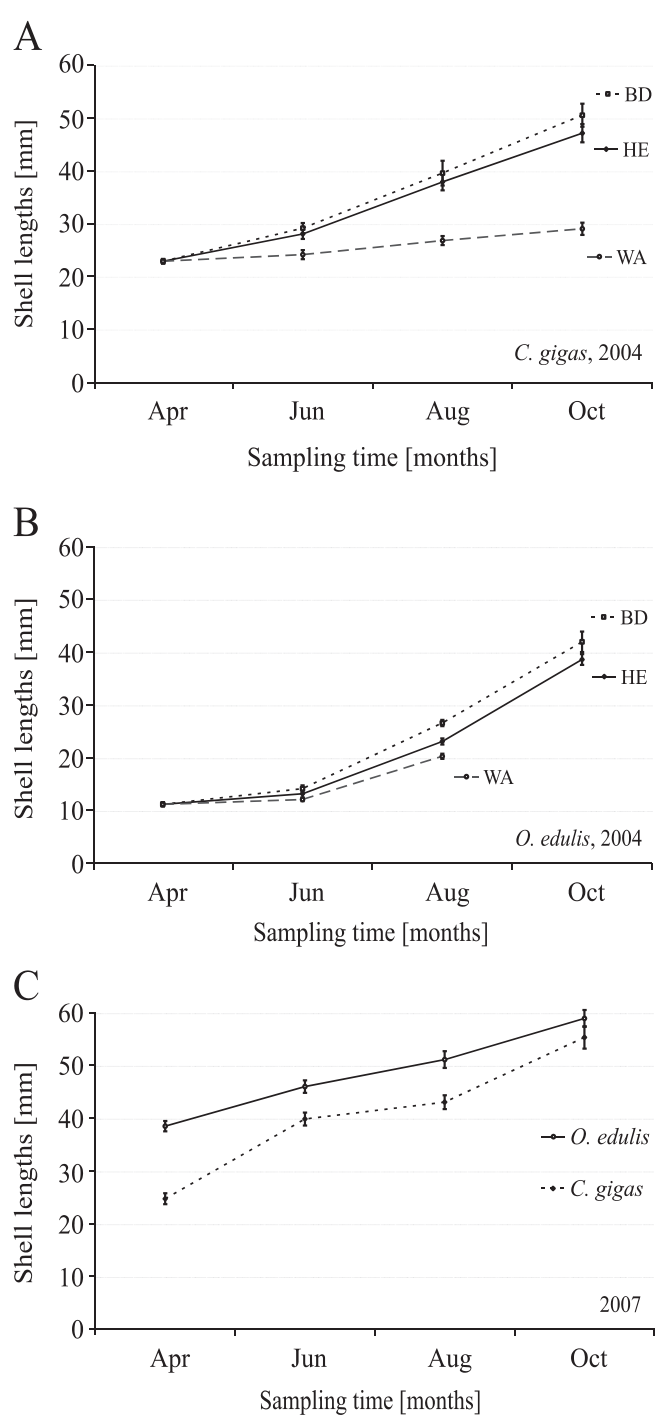

Fig. 3. Shell growth of $C$. gigas (A) and O. edulis (B) at test sites: Butendiek (BD), Helgoland (HE) and Wurster Arm (WA) during the preliminary experiment (2004). $n \approx 50$ per species, sampling date and site. (C) Shell growth of $O$. edulis and C. gigas during the main experiment (2007) at test site Nordergründe (NG). $n \approx 80$ per species and sampling date. Graphs displayed include the mean increase in shell length $(\mathrm{mm}) \pm$ confidence interval.

rather constant increase in shell length (Fig. 3C). Daily growth rates at the different sites (and years) are shown in Table 3. They were very similar for both species at sites BD (C. gigas $0.17 \mathrm{~mm} / \mathrm{d}$, $O$. edulis $0.18 \mathrm{~mm} / \mathrm{d}$ ), HE (C. gigas $0.15 \mathrm{~mm} / \mathrm{d}$, O. edulis $0.16 \mathrm{~mm} / \mathrm{d}$ ), and in the same range at NG (C. gigas $0.19 \mathrm{~mm} / \mathrm{d}, O$. edulis $0.13 \mathrm{~mm} / \mathrm{d})$. Only at site WA growth rates were significantly lower (C. gigas $0.02 \mathrm{~mm} / \mathrm{d}$, 0 . edulis $0.06 \mathrm{~mm} / \mathrm{d})(p<0.01)$. Both species showed considerable intraspecific variability in growth success at all sites. To highlight

Table 3

Growth rates of Crassostrea gigas and Ostrea edulis presented as daily increase of shell length (SL) and dry mass (DM) at the four test sites.

\begin{tabular}{|c|c|c|c|c|c|c|}
\hline \multirow[t]{2}{*}{ Test site } & \multirow[t]{2}{*}{ Code } & \multirow[t]{2}{*}{ Year } & \multicolumn{2}{|c|}{$\begin{array}{l}\text { Increase of } \mathrm{SL} / \mathrm{d} \\
{[\mathrm{mm}]}\end{array}$} & \multicolumn{2}{|c|}{$\begin{array}{l}\text { Increase of } \mathrm{DM} / \mathrm{d} \\
{[\mathrm{mg}]}\end{array}$} \\
\hline & & & C. gigas & O. edulis & C. gigas & O. edulis \\
\hline Butendiek & $\mathrm{BD}$ & 2004 & 0.17 & 0.18 & 2.31 & 1.14 \\
\hline Helgoland & $\mathrm{HE}$ & 2004 & 0.15 & 0.16 & 1.93 & 0.95 \\
\hline Wurster Arm & WA & 2004 & 0.02 & 0.06 & 0.86 & 0.25 \\
\hline Nordergründe & NG & 2007 & 0.19 & 0.13 & 2.33 & 4.57 \\
\hline
\end{tabular}



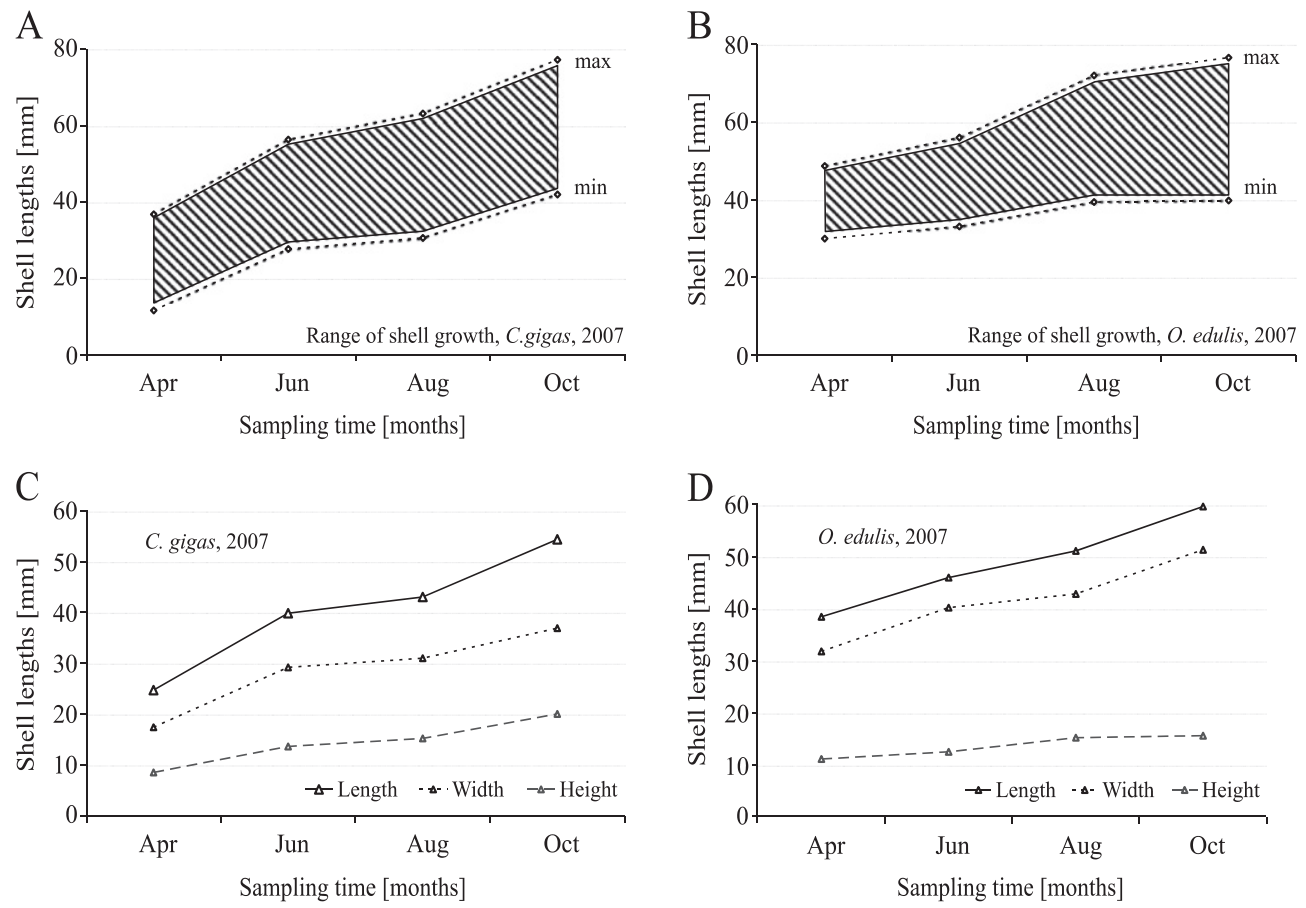

Fig. 4. Growth range (minimum and maximum growth of shell length) of C. gigas (A) and O. edulis (B) during the main experiment (2007). Species-specific shell growth (length, width, thickness) of C. gigas (C) and O. edulis (D) in the main experiment (2007).

these differences the range of shell lengths of $C$. gigas and 0 . edulis in the experiment 2007 is presented in Fig. 4A-B. The two oyster species showed clear differences in terms of shell length, width, height and absolute size because of their species-specific morphology (Newkirk et al., 1995; Walne, 1979). O. edulis is rather round, whereas C. gigas shows a more elongated morphology (Fig. 4C-D).

\subsection{Dry mass, condition index and mortality}

Dry mass of both species increased during cultivation time at all sites in 2004 as well as in 2007 (Fig. 5A-C). In 2004 low growth rates in terms of increasing dry mass were observed for both species at site WA (C. gigas $0.86 \mathrm{mg} / \mathrm{d}, 0$. edulis $0.25 \mathrm{mg} / \mathrm{d}$ ) and significantly higher rates $(p<0.01)$ at $\mathrm{HE}($ C. gigas $1.93 \mathrm{mg} / \mathrm{d}$, O. edulis $0.95 \mathrm{mg} / \mathrm{d})$, and $\mathrm{BD}$ (C. gigas $2.31 \mathrm{mg} / \mathrm{d}$, O. edulis $1.14 \mathrm{mg} / \mathrm{d}$ ) (Table 3). In 2007 both species showed a similar increase in dry mass during springtime. Afterwards different performances were observed for the two species: 0 . edulis individuals grew slightly slower in summer than in spring but growth increased again in autumn. C. gigas individuals showed no length changes during summer, however, marginal increases in dry mass in during autumn were observed (Fig. 5C). C. gigas obtained the highest daily increase in dry mass at sites BD and NG (same growth rates in 2004 and 2007). Clearly lower increases in dry mass were observed in 2004 for individuals of 0 . edulis. In the main experiment of 2007 (site NG) growth rates of 0 . edulis $(4.57 \mathrm{mg} / \mathrm{d}$ ) were almost two times higher than those of $C$. gigas $(2.33 \mathrm{mg} / \mathrm{d}$ ) (Table 3$)$.

Condition index $(\mathrm{CI})$ of the Pacific oysters ranged between $3.4 \pm$ 0.12 and $11.8 \pm 0.37$ at all sites (Fig. $5 \mathrm{E}$ ). Corresponding values for the European oysters ranged between $1.8 \pm 0.02$ and $4.8 \pm 0.13$ in the preliminary experiment (2004) and were higher (between $5.2 \pm 0.26$ and $7.2 \pm 0.22$ ) in the main experiment (2007) (Fig. 5F). In the preliminary experiment values for both species increased during cultivation at sites BD and HE. C. gigas obtained the highest $\mathrm{CI}$ at $\mathrm{BD}$ $(10.0 \pm 0.31)$ and similar characteristics at $\mathrm{HE}$ but with lower values $(7.7 \pm 0.29)$ at the end of the cultivation period. Data for 0 . edulis show similar inclines for $\mathrm{BD}$ and $\mathrm{HE}$ with maximum values ( $4.8 \pm 0.13$ and $4.6 \pm 0.07)$ at the end of the cultivation period. Only at WA a different pattern was observed: In June $C$. gigas obtained values similar to those at $\mathrm{BD}$ and $\mathrm{HE}$. Subsequently the $\mathrm{CI}$ remained constant and after August even a slight decrease in $\mathrm{CI}$ was observed. O. edulis obtained values similar to those at BD and HE in June and August at WA but no values exist for October due to mortality after the sampling in August. In the main experiment $C$. gigas showed a high $\mathrm{CI}$ after the spring period $(11.8 \pm 0.37)$ which decreased during the rest of the sampling season with faster rates in summer and slightly slower rates in autumn (Fig. 5E). O. edulis also showed the highest CI after the spring period $(7.2 \pm 0.2)$ and a decrease during summer. In contrast to C. gigas a slight increase was observed for 0 . edulis in autumn (Fig. 5F).

In 2004 mortality was low $(<3.2 \%)$ for both species at sites BD and HE. However, at site WA O. edulis individuals died after August. In 2007 (NG), mortality was low $(<1 \%)$ for both species during the entire sampling period (Fig. 5D).

\section{Discussion}

Offshore cultivation of oysters is mentioned and recommended in various publications (e.g. Chávez-Villalba et al., 2010; Delmendo, 1998; Goulletquer, 1998; Handley \& Jeffs, 2003), however, none of these publications give attention to "real" offshore conditions as defined by Ryan (2005) and Buck (2007) for open-ocean or offshore aquaculture, namely a high-energy environment with strong currents and high waves. Therefore, no data on offshore farming of oysters among those conditions were available so far to allow comparison of the results of our test animals.

In this study we investigated the biological response of Pacific and European oysters in high-energy environments in terms of growth performance, condition and survival rates.

\subsection{Growth}

The results of the length increase in this study show that both $C$. gigas and $O$. edulis can grow successfully at exposed conditions in an offshore environment. $O$. edulis and $C$. gigas were reared outside their natural coastal habitat, which is normally located on seabeds of the 
A

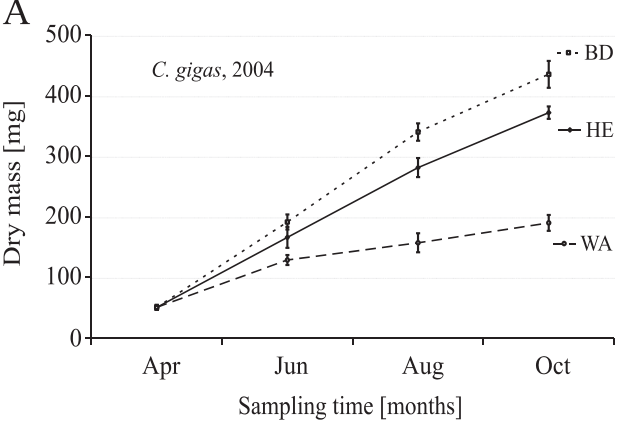

C

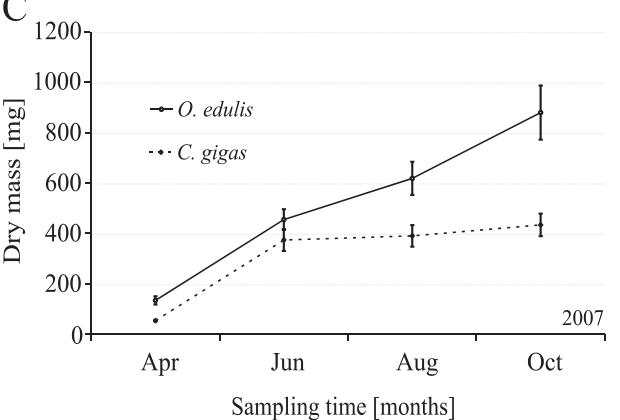

E

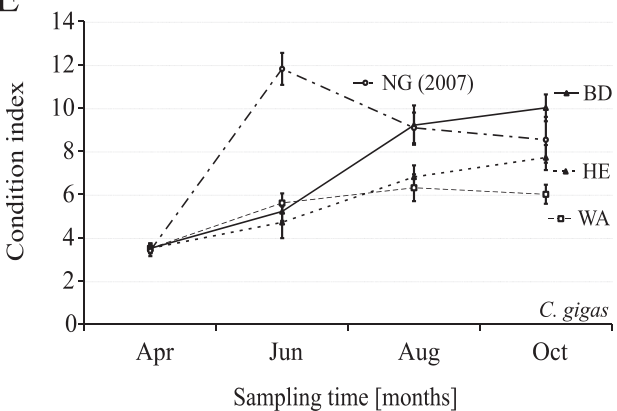

B

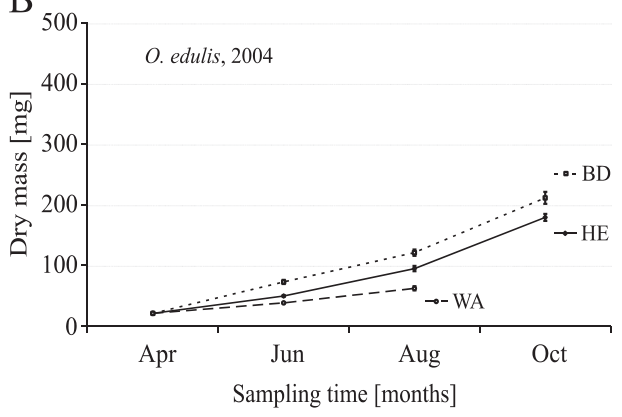

D

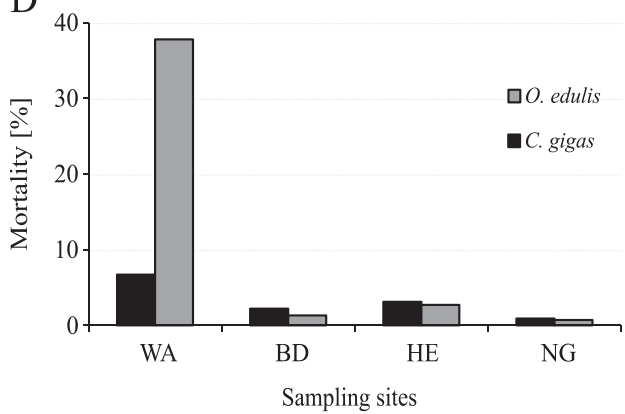

F

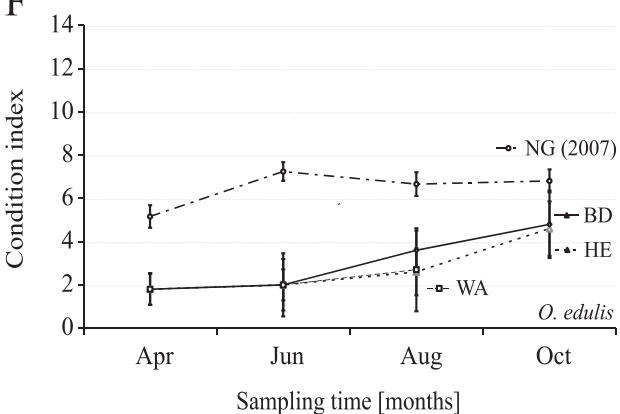

Fig. 5. Dry mass of C. gigas (A) and O. edulis (B) at test sites: Butendiek (BD), Helgoland (HE) and Wurster Arm (WA) during the preliminary experiment (2004). (C) Dry mass of O. edulis and C. gigas during the main experiment (2007) at test site Nordergründe (NG). Graphs present the mean increase in shell length (mm) \pm confidence interval. Mortality (D) and condition index of C. gigas (E) and O. edulis (F) in 2004 and 2007 at the different test sites. $n \approx 50$ per species, sampling date and site. (F) Please note: Lines WA, HE and BD are overlapping from April to June, and Lines WA and HE from June to August. Line WA ends in August.

coastal sea. The animals obtained positive growth rates in terms of shell length and dry mass. However, the duration of the project did not allow the farming of oysters to market size. Nevertheless, this time period allows an estimation of oyster growth over a certain life span. Accepting the lack of growth data of offshore grown oysters, mean growth rates are still comparable to those measured of individuals from nearshore coastal areas (Diederich, 2006; Robert et al., 1991, 1993; Schmidt et al., 2008; Valero, 2006; Walne \& Mann, 1975). Following Valero (2006) there is evidence that juvenile oysters show high length growth in their first year which means that they primarily invest in shell development before flesh biomass starts to increase. In the second and third year they change to higher growth of their body mass. Oysters of this study still grew in the first year of the typical oyster cultivation period. They showed an accelerated length increment, which in turn underlines the projected development.

Seasonal differences in growth performance were observed for the Pacific oyster in the main experiment. The European oyster showed a more constant increase in shell length and dry mass at the same site (NG). The experimental set-up at NG was only conducted in 2007 and no data of other seasons at the same site were available for comparison. However, we assume a higher ability of dietary assimilation, when food availability is low in summer (Rick et al., 2006) and a better adaptation of the native European oyster to this region (Matthiessen, 2001; Newkirk et al., 1995) instead of its counterpart, the introduced Pacific oyster (Andrews, 1980; Chew, 1990; Ruesink et al., 2005).

Oysters of the present study produced an esthetic shell and achieved their species-specific morphology, which plays an important role for their market value in Europe (Matthiessen, 2001). Only oysters grown at Wurster Arm (WA) developed a different shape: Thicker shells and a very compact appearance indicate that animals strongly invested in shell growth to withstand the high currents as well as to prevent shell abrasion (Newkirk et al., 1995).

Mean growth rates in terms of shell length and dry mass strongly depended on the different culture sites. Both oyster species preferred the same sites: At the sites Butendiek (BD) and Nordergründe (NG), both species showed the highest growth rates. As the Pacific oyster showed very similar daily increases in dry mass at both sites, we assume that the sites BD and NG offer similar good conditions for cultivation. However, the European oyster performed differently: Daily increase in dry mass was four times higher at NG (main experiment, 2007) than at BD (preliminary experiment, 2004). We assume that the reason for this different growth development originates in the condition of the spat regarding its larval source. In the preliminary experiment of 2004 European oysters were obtained from the Danish Shellfish Centre (DSC), which started land-based 
cultivation of 0 . edulis in 2002. Løfstedt (2010) indicated poor conditions for some of the first generations of oyster spat produced at DSC, thus, data on growth rates and mortality of $O$. edulis in the preliminary experiment have to be interpreted with caution. This could explain the deviating results for the European oyster at sites BD and NG. As O. edulis of DSC shows positive growth rates in 2004, the question arises, if growth rates could have been even higher with spat animals, which had optimum condition initially. We conclude that $O$. edulis individuals used for the preliminary cultivation experiment in 2004 were in poor condition and too small to move off the coast. After Buck (2002) only those organisms are appropriate for offshore cultivation that are healthy and comprise a certain size class, which is characterized by sufficient robustness. According to typical size classes used in commercial aquaculture farms, larger 0 . edulis spat from a Norwegian producer was used in the main experiment (Buck, 2002; Matthiessen, 2001; Newkirk et al., 1995; Draver, pers. comm.). These animals yielded higher growth rates, even exceeding those of Pacific oysters. The better condition of these animals is reflected in the higher condition index of European oysters in the main experiment.

\subsection{Condition}

The condition index of various oyster species such as 0 . edulis, C. gigas, $C$. virginica etc. is commonly used to evaluate the effects of the surrounding environment on these organisms (Rheault \& Rice, 1996). It is an adequate parameter to describe the commercial quality and physiological state (health) of bivalve molluscs (Dridi et al., 2007). In shellfish production, the most commonly applied condition index (CI) is the ratio of flesh mass to shell mass (Davenport \& Chen, 1987). The data on the condition of both oyster species support the positive results observed for the growth performance at offshore sites. Condition index values for the Pacific oyster indicate good condition (Linehan et al., 1999) in both experiments. Values for the European oyster also indicate good condition in the 2007 experiment. In contrast, condition indices were quite low at the beginning of the preliminary experiment in April 2004, confirming the poor condition of the DSC oyster spat. But the CI increased with cultivation time and the European oyster showed a better condition (Linehan et al., 1999; Walne \& Mann, 1975) at the end of the experiment in October 2004. Apparently, O. edulis was capable of an excellent recovery at sites BE and HE. The condition index showed seasonal variations for both species. Similar variations have also been reported for cultured oysters in coastal areas of Western Europe (Abad et al., 1995; Linehan et al., 1999; Ruiz et al., 1992; Soletchnik et al., 2006) and South Australia (Li et al., 2009). These variations are generated by changing food supply and in adult individuals by gametogenesis and spawning (Li et al. 2009; Soletchnik et al., 2006). In summer 2007 only slow growth in terms of dry mass was observed for the Pacific oyster. This resulted in a decline of the $\mathrm{CI}$, which has also been reported for late summer/autumn in South Australia (Li et al., 2009). Similarly, a slight decline of the $\mathrm{Cl}$ could be observed for the European oyster. Whereas the $\mathrm{CI}$ of $O$. edulis showed a little increase again after August, $C$. gigas did not recover. This is another indication for a better adaptation of the European oyster to this region.

\subsection{Survival rates}

Survival rates for both oyster species (>99\% in 2007) were very high and appropriate for the culture of marine organisms and are rarely achieved in commercial oyster aquaculture production (Chávez-Villalba et al., 2010; Costil et al., 2005; Soletchnik et al., 2006; Valero, 2006). High survival or low mortality rates of Pacific oysters have also been reported for wild banks in the German Wadden Sea (Diederich, 2006; Schmidt et al., 2008) and for oyster cultures in South Australia (Li et al., 2009). However, in 2004 a high mortality rate was only observed for 0 . edulis at one single site: At site WA, animals died some time after the sampling period in August. This mass die-off could have been caused by the high sediment-load in the water column at this site (BSH, 2011), since natural 0 . edulis oyster beds are never found on muddy sediments (OSPAR, 2009). The presence of high quantities of silt in the water can block the digestive and respiratory tracts, causes stress to the animal and results in the death of the oyster after a certain time (Laing et al., 2005; Partridge, 1981). Additionally, due to the short distance of this site to the port of Bremerhaven, urban sewage or contaminants could have affected the water quality. In general, high mortality of oysters can be correlated to energy expenditure during spawning, high water temperatures in summer as well as the result of multiple stressors (e.g. low salinity, low dissolved oxygen, pathogens) creating physiological pressure (Costil et al., 2005; Soletchnik et al., 2006).

The high survival rates presented in this study indicate that water conditions at the other offshore cultivation sites have no negative impact on the survival of the tested oyster species. This is supported by the fact that natural banks of the European oysters also occurred in deeper waters and offshore down to $50 \mathrm{~m}$, e.g. in the North Sea and the eastern English Channel (OSPAR, 2009).

\subsection{Site-specific performance}

In the experiments of 2004 and 2007 oysters were cultivated at four different sites. Due to the varying conditions from site to site, differences in growth performance, condition and survival were observed. To evaluate these sites regarding site selection criteria, biotic and abiotic parameters (e.g. temperature, salinity, nutritional situation) and their impact on the overall condition of the candidates were examined.

No significant differences in temperature and salinity were detected between the three offshore cultivation sites. The growing season of oysters depends on temperature and naturally proceeds from April until late September in the North Atlantic (Korringa, 1952; Matthiessen, 2001; Walne \& Mann, 1975). As C. gigas tolerates a wide range of temperatures and cultivated $O$. edulis individuals belong to the well-adapted cold-water population (OSPAR, 2009), no seasonal temperature abnormalities were observed. Additionally, salinity is known to be very stable at offshore sites and both species prefer the marine and fully saline conditions that characterize those areas (Laing et al., 2005).

Oysters are supplied with food and oxygen and relieved from waste products through the action of hydrodynamic currents. Since filtration rate and food availability increase with flow rate (Walne, 1972; 1979), oysters were expected to grow better at cultivation sites with stronger water currents (Valero, 2006). Although offshore areas are known to offer lower plankton concentrations compared to coastal regions (Ducrotoy et al., 2000), the higher hydrodynamic flow offshore can compensate for this limitation. However, the offshore test sites in the present study resemble special conditions as the North Sea shows symptoms of eutrophication. Additionally, turbid areas, like estuaries and their run-offs, can be classified as hyper-nutrified systems where food supply is regarded to be sufficient (Ducrotoy et al., 2000). The combination of current speed and food amount implies high food availability at the offshore sites BD and NG with high current speed. WA, also a site with high currents, deviated from that scheme. As described above, oysters did not show successful growth rates and the shell morphology indicated mechanical stress. Former studies have shown that filtration rates increase with increased flow rates until a maximum value when oysters are unable to remove more particles from the water passing by (Walne, 1979). Apparently, current forces at WA exceeded this maximum. Furthermore, low salinity values at this site could have resulted in physiological stress for the oysters and affected their growth success (Laing et al., 2005).

In the preliminary experiment, test site Butendiek (BD) showed the best results. The distribution of nutrients and plankton in the German Bight follows the current system, a counter-clockwise gyre parallel to 
the coast (Ducrotoy et al., 2000, Mittelstaedt et al., 1983). Hence, nutrients from river run-offs and the coast are transported to the north (BSH, 2004). Subsequently, high plankton production can be observed parallel to the coast of the North Frisian Wadden Sea and around the area of the test site BD (Ducrotoy et al., 2000; WeigeltKrenz et al., 2010). This situation provides optimal nutritional conditions for the cultivated oysters. Results of similar quality in terms of shell growth were found at test site Helgoland (HE). However, the area around Helgoland is located further offshore, outside of the nutrient-rich zone of the German Bight (Weigelt-Krenz et al., 2010). Correspondingly, slightly lower growth rates (dry mass) of the Pacific oyster indicate a different food situation at this site. At site Wurster Arm (WA) low salinity and a high sediment load of water originating from the Wadden Sea (BSH, 2004) may explain the low growth success. Poor growth performances of both species and the high mortality of the European oyster lead to the conclusion that this site is not adequate for aquaculture production.

Consequently, for the main experiment in 2007 it was aimed for a cultivation site, which fulfills the described site selection criteria and offers the same quality as site BD. De facto, growth performance, condition and survival of both oyster species showed the expected success at the selected site Nordergründe (NG).

\section{Conclusions and outlook}

This study shows that juvenile oysters (1) exhibit a convincing growth performance at offshore sites, (2) are in strong condition, and (3) cope well with rough conditions. Subsequently, from an oyster farmer perspective, these data attest the suitability of open ocean environments for oyster cultivation and encourage aquaculture activities at offshore sites. Both, C. gigas and O. edulis, respectively, play a significant contributor to the European economy, especially on the oyster half shell market in France. Generally, the oyster trade is of enormous commercial importance with wholesale average prices for the European oyster commonly being 3 to 5 times higher than for the Pacific oyster. Following Goulletquer (2004), O. edulis fills an economic niche as a premium seafood item. Therefore, oysters as high-value products would be potential candidates for offshore cultivation since an economic analysis for mytiliculture by Buck et al. (2010) have calculated higher costs when moving far off the coast.

Our experiments clearly reveal indications that the native species is very well adapted (Matthiessen, 2001; OSPAR, 2009) and shows an adequate growth performance. Therefore, the cultivation of the European flat oyster in the North Sea is recommended in particular.

Assuming appropriate site selection criteria, we conclude that both oyster species, $C$. gigas and $O$. edulis, are successful candidates for offshore cultivation. A multiple-use of potential offshore locations together with other users, e.g. offshore wind farms is promising and synergistic effects may offer technical and financial advantages to oyster farmers.

Future studies will focus on physiological parameters and fitness indicators of oysters cultivated at offshore sites. Additionally, complete grow-out periods during various seasons should be examined to increase knowledge about oyster culture experiments off the coast.

\section{Acknowledgements}

We thank the Water and Shipping Authority, namely Mr. Boening and the Captain and Crew of the MV Bruno Illing and MV Mellum for their support in maintaining the test sites Wurster Arm and Nordergründe. Thanks are expressed to the captain and crew of the research vessel Uthörn for their assistance. We also thank the AWIdiving group for technical support and all divers involved in this project. Thanks go to Dr. Matthias Brenner (IMARE) who provided environmental data from the support program of the Mytifit-Project and to Dr. Susanne Tamm from the German Oceanographic Data Centre (DOD) for her help with the databases of the BSH. The research carried out for this manuscript has been funded by the University of Bremen and the Alfred Wegener Institute for Polar and Marine Research and is further a partial fulfillment for a Doctoral degree of the leading author.

\section{References}

Abad, M., Ruiz, C., Martinez, D., Mosquera, G., Sánchez, J.L., 1995. Seasonal variations of lipid classes and fatty acids in flat oyster, Ostrea edulis, from San Cibran (Galicia, Spain). Comp. Biochem. Physiol. 110 (2), 109-118.

Andrews, J.D., 1980. A review of introductions of exotic oysters and biological planning for new importations. Mar. Fish. Rev. 42, 1-11.

Barnaby, R., 2006. Lessons learned - making cooperative fisheries research work, panel summary. Partnerships for a Common Purpose. Coop. Fish. Res. Manage. 52, $123-128$.

Beninger, P.G., Lucas, A., 1984. Seasonal variations in condition, reproductive activity, and gross biochemical composition of two species of adult clam reared in a common habitat: Tapes decussates L. (Jeffreys) and Tapes philippinarum (Adams \& Reeve). J. Exp. Mar. Biol. Ecol. 79, 19-37.

Brenner, M., 2009. Site selection criteria and technical requirements for the offshore cultivation of Blue mussels (Mytilus edulis L.). PhD Thesis. Jacobs University Bremen, Germany.

Brenner, M., Buck, B.H., Koehler, A., 2007. New concept combines offshore wind farms, mussel cultivation. Glob. Aquac. Adv. 10 (1), 79-81.

BSH, 2004. Berichte des Bundesamtes fuer Seeschifffahrt und Hydrographie 40, Hamburg, Germany. Nordseezustand. 219 pp.

BSH, 2006. Marine Environmental Database (MUDAB). Bundesamt für Seeschifffahrt und Hydrographie (BSH), Hamburg, Germany.

$\mathrm{BSH}, 2009$. Marine environment reporting system information for the North Sea and Baltic Sea (MURSYS). Bundesamt für Seeschifffahrt und Hydrographie (BSH), Hamburg, Germany. Online data acquisition. http://www.bsh.de. (accessed November 2010).

BSH, 2011. Version 3. Bundesamt für Seeschifffahrt und Hydrographie (BSH), Hamburg, Germany. The Operational Circulation Model BSHcmod.

Buck, B.H., 2002. Open ocean aquaculture und Offshore-Windparks: Eine Machbarkeitsstudie über die multifunktionale Nutzung von Offshore-Windparks und Offshore Marikultur im Raum Nordsee. Reports on Polar and Marine Research. Bremerhaven 412, 1-252.

Buck, B.H., 2007. Experimental trials on the feasibility of offshore seed production of the mussel Mytilus edulis in the German Bight: installation, technical requirements and environmental conditions. Helgol. Mar. Res. 61, 87-101.

Buck, B.H., Krause, G., 2011. Integration of aquaculture and renewable energy systems. Chapter No. 180. In: Meyers, R.A. (Ed.), Encyclopedia of Sustainability Science and Technology. Springer Science + Business Media LLC. doi:10.1007/978-1-44190851-3.

Buck, B.H., Krause, G., Rosenthal, H., Smetacek, V., 2003. Aquaculture and environmental regulations: the German situation within the North Sea. In: Kirchner, A. (Ed.), International marine environmental law: institutions, implementation and innovation. International Environmental, 64. Law and Policies Series of Kluwer Law International, The Hague, pp. 211-229.

Buck, B.H., Krause, G., Rosenthal, H., 2004. Extensive open ocean aquaculture development within wind farms in Germany: the prospect of offshore comanagement and legal constraints. Ocean Coast. Manage. 47 (3-4), 95-122.

Buck, B.H., Krause, G., Michler-Cieluch, T., Brenner, M., Buchholz, C.M., Busch, J.A., Fisch, R., Geisen, M., Zielinski, O., 2008. Meeting the quest for spatial efficiency: progress and prospects of extensive aquaculture within offshore wind farms. Helgol. Mar. Res. 62, 269-281.

Buck, B.H., Ebeling, M., Michler-Cieluch, T., 2010. Mussel cultivation as a co-use in offshore wind farms: potentials and economic feasibility. Aquac. Econ. Manage. 14 (4), 255-281.

Burbridge, P., Hendrick, V., Roth, E., Rosenthal, H., 2001. Social and economic policy issues relevant to marine aquaculture. J. Appl. Ichthyol. 17, 194-206.

Chávez-Villalba, J., Arreola-Lizárraga, A., Burrola-Sánchez, S., Hoyos-Chairez, F., 2010. Growth, condition and survival of the Pacific oyster Crassostrea gigas cultivated within and outside a subtropical lagoon. Aquaculture 300, 128-136.

Chew, K.K., 1990. Global bivalve shellfish introductions. World Aquac. 21, 9-22.

Costil, K., Royer, J., Ropert, M., Soletchnik, P., Mathieu, M., 2005. Spatio-temporal variations in biological performances and summer mortality of the Pacific oyster Crassostrea gigas in Normandy (France). Helgol. Mar. Res. 59, 286-300.

Davenport, J., Chen, X., 1987. A comparison of methods for the assessment of condition in the mussel (Mytilus edulis L.). J. Moll. Stud. 53, 293-297.

Delmendo, M.N., 1998. Bivalve farming: an alternative economic activity for small-scale coastal fishermen in the ASEAN region. ASEAN/UNDP/FAO Regional Small-Scale Coastal Fisheries Development Project, Manila, Philippines. 43 pp.

Dick, S., 2001. The Operational Circulation Model of BSH (BSHcmod) - Model description and validation. Berichte des BSH 29. . 49 pp.

Diederich, S., 2006. High survival and growth rates of introduced Pacific oysters may cause restrictions on habitat use by native mussels in the Wadden Sea. J. Exp. Mar. Biol. Ecol. 328, 211-227.

Dridi, S., Romdhane, M.S., Elcafsi, M., 2007. Seasonal variation in weight and biochemical composition of the Pacific oyster, Crassostrea gigas in relation to the gametogenic cycle and environmental conditions of the Bizert lagoon, Tunisia. Aquaculture 263, 238-248. 
Ducrotoy, J.P., Elliott, M., DeJonge, V.N., 2000. The North Sea. Mar. Pollut. Bull. 41 (1-6), 5-23. Energiekontor, 2011. Official homepage of the project developer Energiekontor. www. energiekontor.de. (accessed February 2011).

FAO, 2009. The State of World Fisheries and Aquaculture - 2008 (SOFIA). FAO Fisheries and Aquaculture Department. $176 \mathrm{pp}$.

FAO, 2011. Fisheries and Aquaculture Information and Statistics Service. www.fao.org fishery/aquaculture/en. (accessed January 2011).

Ferreira, J.G., Sequeira, A., Hawkins, A.J.S., Newton, A., Nickel, T.D., Pastres, R., Forte, J. Bodoy, A., Bricker, S.B., 2009. Analysis of coastal and offshore aquaculture: application of the FARM model to multiple systems and shellfish species. Aquaculture 289, 32-41.

Firestone, J., Kempton, W., Krueger, A., Loper, C.E., 2004. Regulating offshore wind power and aquaculture: messages from land and sea. Cornell J. Law Public Policy 14 (1), 71-111.

Garen, P., Robert, S., Bougrier, S., 2004. Comparison of growth of mussel, Mytilus edulis, on longline, pole and bottom culture sites in the Peruis Breton, France. Aquaculture 232, 511-524

Gibbs, M.T., 2004. Interactions between bivalve shellfish farms and fishery resources. Aquaculture 240, 267-296.

Gierloff-Emden, H.G.R., 2002. Wandel der Umwelt der See- und Küstenlandschaft der Nordsee durch Nutzung von Windenergie. Mitt. Österr. Geol. Ges. 144, 219-226.

Goulletquer, P., 1998. Shellfish production in France: present situation and new approaches to optimize production 19-20 May 1998, London, England: Proceedings of the 29th Annual Conference of the Shellfish Association of the United Kingdom 69-80.

Goulletquer, P., 2004. Cultured Aquatic Species Information Programme. FAO Inland Water Resources and Aquaculture Service (FIRI). http://www.fao.org/figis/servlet/ static?dom $=$ culturespecies $\& \mathrm{xml}=$ Ostrea_edulis.xml. (accessed September 2006)

Handley, S., Jeffs, A., 2003. Assessment of future expansion of Pacific oyster (Crassostre gigas) farming in Northland. NIWA Client Report: AL2003-027, NIWA Project: ENT03101. 31 pp.

Korringa, P., 1952. Recent advances in oyster biology. Q. Rev. Biol. 27 266-308 and 339365.

Krause, G., Buck, B.H., Rosenthal, H., 2003. Multifunctional use and environmental regulations: potential in the offshore aquaculture development in Germany. Rights and Duties in the Coastal Zone: Proceedings of the Multidisciplinary Scientific Conference on Sustainable Coastal Zone Management. 12-14 June 2003, Stockholm, Sweden, 6 pp.

Laing, I., Walker, P., Areal, F., 2005. A feasibility study of native oyster (Ostrea edulis) stock regeneration in the United Kingdom. CEFAS.

Li, Y., Qin, J.G., Li, X., Benkendorff, K., 2009. Monthly variation of condition index, energy reserves and antibacterial activity in Pacific oysters, Crassostrea gigas, in Stansbury (South Australia). Aquaculture 286, 64-71.

Linehan, L.G., O'Connor, T.P., Burnell, G., 1999. Seasonal variation in the chemical composition and fatty acid profile of Pacific oysters (Crassostrea gigas). Food Chem. 64, 211-214.

Løfstedt, M.B., 2010. The effect of food quality on glycogen content, the fatty acid profile and winter mortality in cultivated oyster spat (Ostrea edulis). Aquac. Nutr. 16, 625-636.

Matthiessen, G.C., 2001. Oyster Culture. Fishing News Books, London. 163 pp.

McElwee, J., 1998. The sociological and environmental impacts of open ocean aquaculture. In: Stickney, R.R. (Ed.), Joining forces with industry - open ocean aquaculture, Proceedings of the Third Annual International Conference 10-15 May 1998. Texas Sea Grant College Program, Corpus Christi, pp. 31-35.

Mittelstaedt, E., Lange, W., Brockmann, C., Soetje, K.C., 1983. Die Strömungen in der Deutschen Bucht. Deutsches Hydrographisches Institut, Hamburg. 142 pp.

Newkirk, G.F., Muise, B., Enright, C.T., 1995. Culture of the Belon Oyster, Ostrea edulis, in Nova Scotia. In: Boghen, A.D. (Ed.), Cold-Water Aquaculture in Atlantic Canada. Canadian Institute for Research on Regional Development, pp. 225-253.

OSPAR, 2009. Background document for Ostrea edulis and Ostrea edulis beds Biodiversity Series 428. OSPAR Commission. 22 pp. (accessed February 2011).
Partridge, K., 1981. A manual for Irish Oyster Farmers. Aquac. Techn. Bull. 1, 48-60.

Rheault, R.B., Rice, M.A., 1996. Food-limited growth and condition index in the eastern oyster, Crassostrea virginica (Gmelin 1791), and the bay scallop, Argopecten irradians (Lamarck 1819). J. Shellfish. Res. 15 (2), 271-283.

Rick, H.J., Rick, S., Tillmann, U., Brockmann, U., Gaertner, U., Duerselen, C. Suendermann, J., 2006. Primary Productivity in the German Bight (1994-1996). Estuar. Coast. 29, 4-23.

Robert, R., Borel, M., Pichot, Y., Trut, G., 1991. Growth and mortality of the European oyster Ostrea edulis in the Bay of Arcachon (France). Aquat. Living Resour. 4 265-274.

Robert, R., Trut, G., Borel, M., Maurer, D., 1993. Growth, fatness and gross biochemical composition of the Japanese oyster, Crassostrea gigas, in Stanway cylinders in the Bay of Arcachon, France. Aquaculture 110 (3-4), 249-261.

Rose, J.M., Tedesco, M., Wikfors, G.H., Yarish, C., 2010. International Workshop on Bioextractive Technologies for Nutrient Remediation Summary Report. International Workshop on Bioextractive Technologies for Nutrient Remediation. Dec 3-4, 2009. National Oceanic and Atmospheric Administration (NOAA, University of Connecticut, Stamford, USA. Northeast Fisheries Science Center Reference Document 10-19, $18 \mathrm{pp}$.

Ruesink, J.L., Lenihan, H.S., Trimble, A.C., Heiman, K.W., Micheli, F., Byers, J.E., Kay, M.C., 2005. Introduction of non-native oysters: ecosystem effects and restoration implications. Annu. Rev. Ecol. Evol. Syst. 36, 643-689.

Ruiz, C., Martinez, D., Mosquera, G., Abad, M., Sánchez, J.L., 1992. Seasonal variations in condition, reproductive activity and biochemical composition of the flat oyster Ostrea edulis, from San Cibran (Galicia, Spain). Mar. Biol. 112, 67-74.

Ryan, J., 2005. Offshore aquaculture - do we need it, and why is it taking so long? International Salmon Farmers Association (Ireland). Expert workshop on "Sustainable Aquaculture. DG JRC European Commission, Institute for Prospective Technological Studies, Seville, Spain. 17-18 Jan 2005,.

Schmidt, A., Wehrmann, A., Dittmann, S., 2008. Population dynamics of the invasive Pacific oyster Crassostrea gigas during the early stages of an outbreak in the Wadden Sea (Germany). Helgol. Mar. Res. 62, 367-376.

Soletchnik, P., Faury, N., Goulletquer, P., 2006. Seasonal changes in carbohydrate metabolism and its relationship with summer mortality of the Pacific oyster Crassostrea gigas (Thunberg) in Marennes-Oléron Bay (France). Aquaculture 252, 328-338.

Takayanagi, K., 1998. Water quality guidelines for aquaculture: an example in Japan. Durham/New Hampshire/USA September 16-18, 1997. UJNR technical report No. 26, In: Howell, W.H., Keller, B.J., Park, P.K., McVey, J.P., Takayanagi, K., Uekita, Y. (Eds.), Nutrition and technical development of aquaculture. Proceedings of the 26th US-Japan aquaculture symposium. University of New Hampshire Sea Grant Program, Durham, pp. 247-254.

Troell, M., Joyce, A., Chopin, T., Neori, A., Buschmann, A.H., Fang, J.G., 2009. Ecologica engineering in aquaculture - potential for integrated multi-trophic aquaculture (IMTA) in marine offshore systems. Aquaculture 297, 1-9.

Valero, J., 2006. Ostrea edulis. Growth and mortality depending on hydrodynamic parameters and food availability. Master Thesis. Department of Marine Ecology University of Göteborg, Sweden. 47 pp.

Walne, P.R., 1972. The influence of current speed, body size and water temperature on the filtration rate of five species of bivalves. J. Mar. Biol. Assoc. UK 52, 345-374.

Walne, P.R., 1979. Culture of Bivalve Molluscs: 50 years experience at Conwy Whitefriars Press, London and Tonbridge.

Walne, P.R., Mann, R., 1975. Growth and biochemical composition in Ostrea edulis and C. gigas. In: Barnes, H. (Ed.), Proc. 9th EMBS Aberdeen, pp. 587-607.

Weigelt-Krenz, S., Hanslik, M., Patsch, J., Petenati, T., Van Beusekom, J., 2010. Nutrients in the German Wadden Sea and German Bight. Meeresumwelt Aktuell Nord- und Ostsee, 2010. 1. $12 \mathrm{pp}$.

Wirtz, K., Tol, R., Hooss, G., 2002. Mythos "Offene See": Nutzungskonflikte im Meeresraum. In: Lozán, J., Rachor, E., Reise, K., Sündermann, J., Westernhagen, H.v. (Eds.), Warnsignale aus Nordsee \& Wattenmeer: Eine aktuelle Umweltbilanz. Wissenschaftliche Auswertungen, Hamburg, pp. 157-160. 